JELENA ANĐELKOVIĆ GRAŠAR

Institute of Archaeology

Belgrade, Serbia

E-mail: j.andjelkovic@ai.ac.rs

EMILIJA NIKOLIĆ

Institute of Archaeology

Belgrade, Serbia

E-mail: e.nikolic@ai.ac.rs
UDC 75.071.1

75.046 .9

Original research article

Received: $25^{\text {th }}$ October 2019

Accepted: $15^{\text {th }}$ November 2019

\title{
MILENA PAVLOVIĆ BARILLI'S PICTORIAL POETICS AND VIMINACIUM LANDSCAPE
}

\begin{abstract}
Since the effects of a landscape go further than geography and beyond the time line, this paper questions the possibility that the Viminacium landscape, the archaeological area near the Danube in Serbia, inspired the art of the internationally recognised painter and poet Milena Pavlovic Barilli. One can try to trace the relationship between Viminacium and Milena's art primarily in the motifs that are associated with Antiquity. Architectural elements, statues or human figures that resemble statues, as well as compositions that refer to the mythological patterns are an indicative part of Milena s pictorial poetics. The greatest influence of ancient material and immaterial heritage on Milena's art is visible in paintings and drawings from the 1930s.
\end{abstract}

KEYWORDS: MILENA PAVLOVIĆ BARILLI, ANTIQUITY, VIMINACIUM, SURREALISM, LANDSCAPE, PAINTING, POETICS.

\section{INTRODUCTION ${ }^{1}$}

Whether talking about the UNESCO category of the associative cultural landscape (UNESCO 2019, Annex 3, par. 10), the inspirational landscape as a category developed by certain heritage organisations (Brown 2008, 2; Context Pty Ltd 2003; Beazley 2004, 1-14; Deacon and Beazley 2007, 93-108; ICOMOS 1995; ICOMOS-IFLA 2017, 33, 60; US-ICOMOS 2004) or the different interpretative landscape categories proposed by anthropologists (Knapp and Ashmore 1999, 1-30), descriptions of these experiential and imaginative

1 The article is a result of the project: Viminacium, Roman city and military camp - research of the material and non material culture of inhabitants by using the modern technologies of remote detection, geophysics, GIS, digitalization and $3 D$ visualization (no 47018), funded by The Ministry of Education, Science and Technological Development of the Republic of Serbia. landscapes are always related to their religious, artistic and cultural meanings. One of the deepest human needs is that for "a sense of identity and belonging", and is found commonly in the landscape seen with the eye, but interpreted with the mind, as was written by Kan Taylor (Taylor 2008, 1). For the painter Milena Pavlović Barilli (1909 1945), the landscape that she was related to in the previously mentioned way was the wider area of the archaeological site of Viminacium, once a Roman city and legionary fortress, founded in the $1 \mathrm{st}$ century AD, whose protected remains today lie in the territories of the Kostolac and Drmno villages in Serbia (Fig. 1), presented within the area of the Viminacium Archaeological Park (Fig. 6b). ${ }^{2}$

2 On today's landscape and the site of Viminacium, see: Nikolić and Roter-Blagojević 2017, 188-204; Nikolić et al. 2017, 573-583; Nikolić et al. 2013, 260-271; Nikolić and Roter-Blagojević 2018, 785-792; Golubović and Korać 2013, 65-73; Anđelković Grašar, Rogić and Niko- 


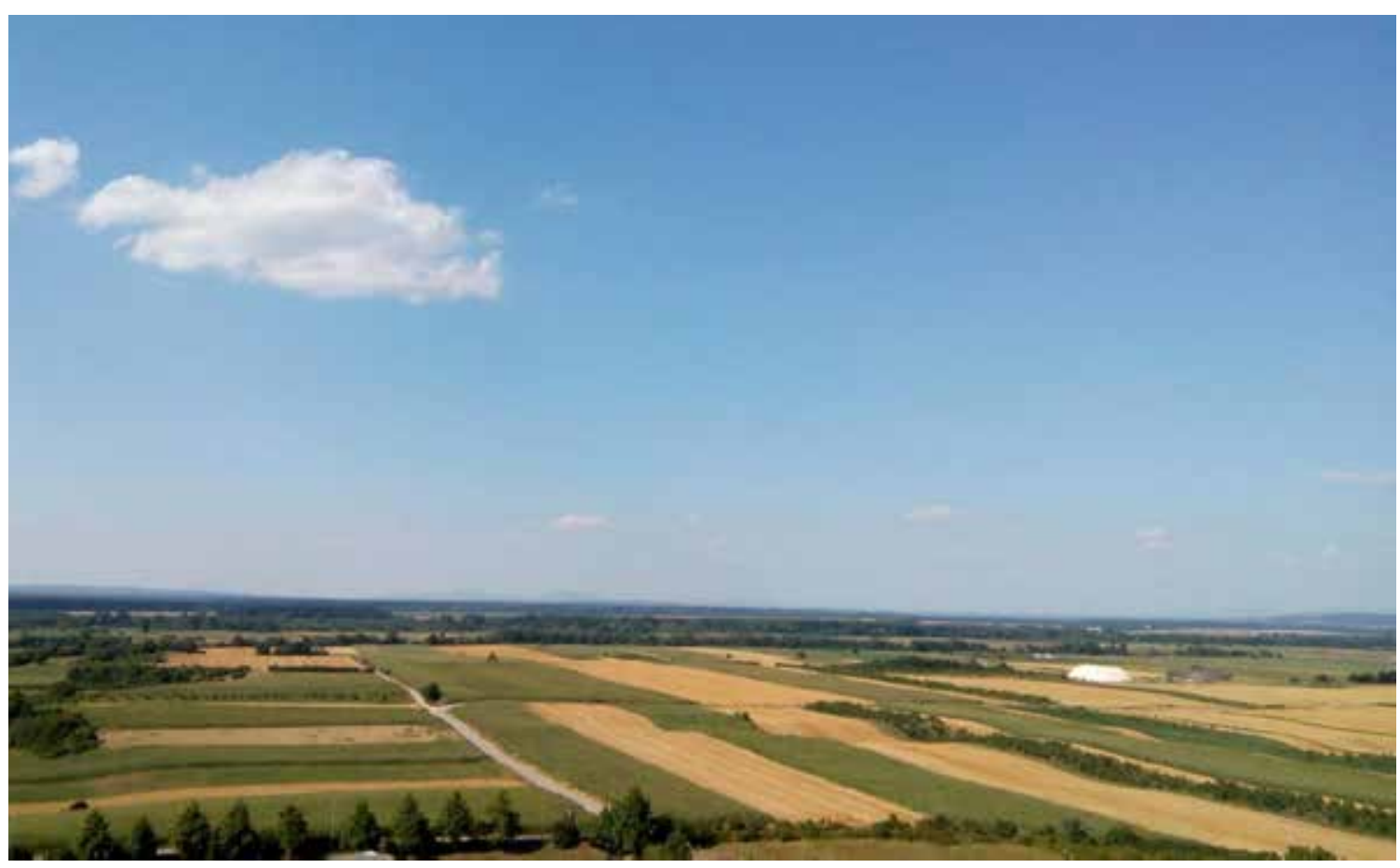

Fig. 1 Viminacium landscape today with ancient remains covered by soil (photo by Emilija Nikolić).

It is widely known that Milena Pavlović Barilli was born in the town of Požarevac in today's Serbia, about $20 \mathrm{~km}$ from the Viminacium archaeological site, as the daughter of the Serbian Danica Pavlović (1883-1965) and Italian Bruno Barilli (1880-1952) (Fig.2). She spent her childhood in Požarevac, but also in many large European cities, completed her studies in painting in Belgrade and Munich, and continued her work in Paris and New York (Fig.3). In 1962, a legacy gallery was opened at her birth house in Požarevac with about nine hundred of her works, as well as many items from her life. ${ }^{3}$

\section{MILENA PAVLOVIĆ BARILLI AND VIMINACIUM}

The period of the end of the $19^{\text {th }}$ century and the beginning of the $20^{\text {th }}$ century was the time of the first archaeological excavations at Viminaci-

lić. 2013, 9-14.

3 Gallery 2019. um, conducted by Mihailo Valtrović (1939-1915) a Serbian architect and art historian, and later by Miloje Vasić (1869-1956) the first Serbian educated archaeologist (Валтровић 1884; Васић 1903a/b). Milena belonged to an aristocratic family; her mother Danica was a descendent of the royal Serbian family of Karađorđević, while her father Bruno was an Italian composer and a music critic. From a young age, she was taught foreign languages, a variety of skills and etiquette, all while travelling throughout Europe with her family. Based on the given preferences, it would be reasonable to suppose that the young Milena probably had an opportunity to visit archaeological sites in the vicinity of her hometown.

It is testified in historical sources and photographs that royals and intellectuals were very much interested in the research of antiquities in $19^{\text {th }}$ century Serbia. Queen Draga Obrenović and King Aleksandar visited Viminacium with their escort during the excavations of Miloje Vasić and donated one hundred ducats to future research (Korać, Golubović 2009, 12) (Fig.4). 


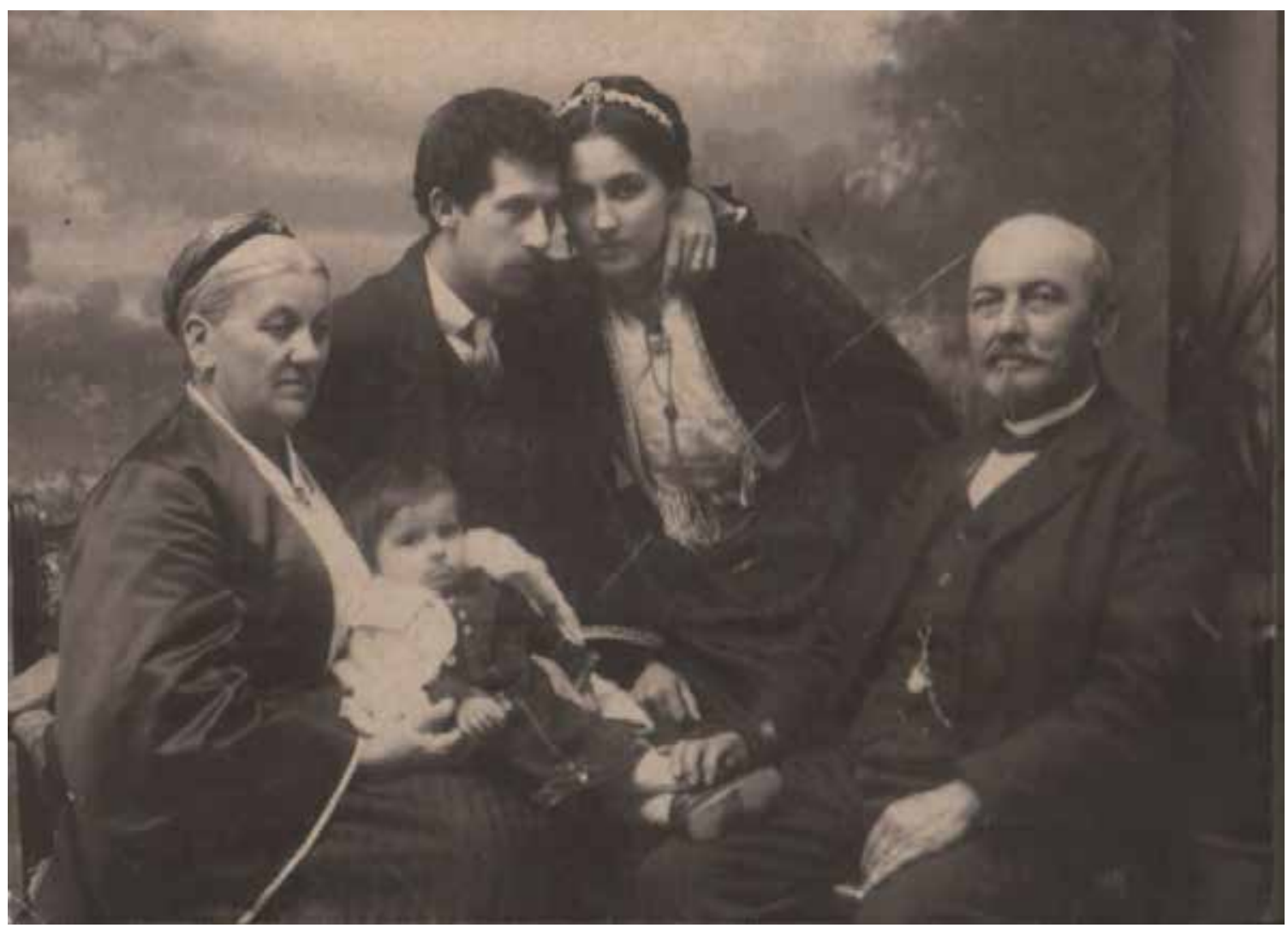

Fig. 2 Milena Pavlović Barilli with her family in 1910 (Galerija Milene Pavlović Barilli. "Galerija slika - porodične fotografije", http://galerijamilenepavlovicbarilli.rs/galerija-slika/, accessed on December, 6th 2019).

The wealthy industrialists of the time, as antique lovers and collectors, tried in many ways to preserve valuable artefacts of the past. At the time of the development of archaeology in Serbia and the beginnings of industrialisation (Спасић 2015, 14), both of which started in Kostolac village, sites were not protected and much depended on the will of individuals. During their work in the Kostolac underground coal mine of Đorđe Vajfert (1850-1937) in the $19^{\text {th }}$ and the beginning of the $20^{\text {th }}$ century, workers would find various artefacts, as well as the remains of architecture, which were collected and later handed over by administrators, engineers, and Vajfert to various institutions, as Mihailo Valtrović, Miloje Vasić and Felix Kanitz (1829-1904) wrote (Валтровић 1886a, 26; Валтровић 1886b, 71-72; Валтровић 1886c, 116; Валтровић 1886d; Валтровић 1890, 56; Васић 1903b, 205; Каниц 1989, 85, 184-185, 190; Сариа 1934, 73-75). In the administration building of the Vajfert mine, Kanitz saw fragments of sarcophagi, sculptures and architecture (Каниц 1989, 85, 184-185). The Danube ship's captain, Dragutin Todić, who transported Kostolac coal, was also a passionate collector of Viminacium antiquities, and he set up a lapidarium of stone monuments with Vajfert, near his villa in the village of Kostolac, wishing to establish a museum there (Спасић-Ђурић 2015, 73-75). In 1934, it was written that finds from Viminacium were housed in the Gymnasium in Požarevac and National Museum in Belgrade, as well as within the Vajfert collection (Миленковић, Протић 1936, 43). Тоdić and Vajfert left their collections to the National Museum in Požarevac, the National Museum in Belgrade and the National Museum in Pančevo (Спасић-Ђурић, 2015, 14) (Fig. 5). The artefacts in the Gymnasium were housed in the building from 1893 and the first museum was founded there in 1895 . As it was robbed and ruined during 


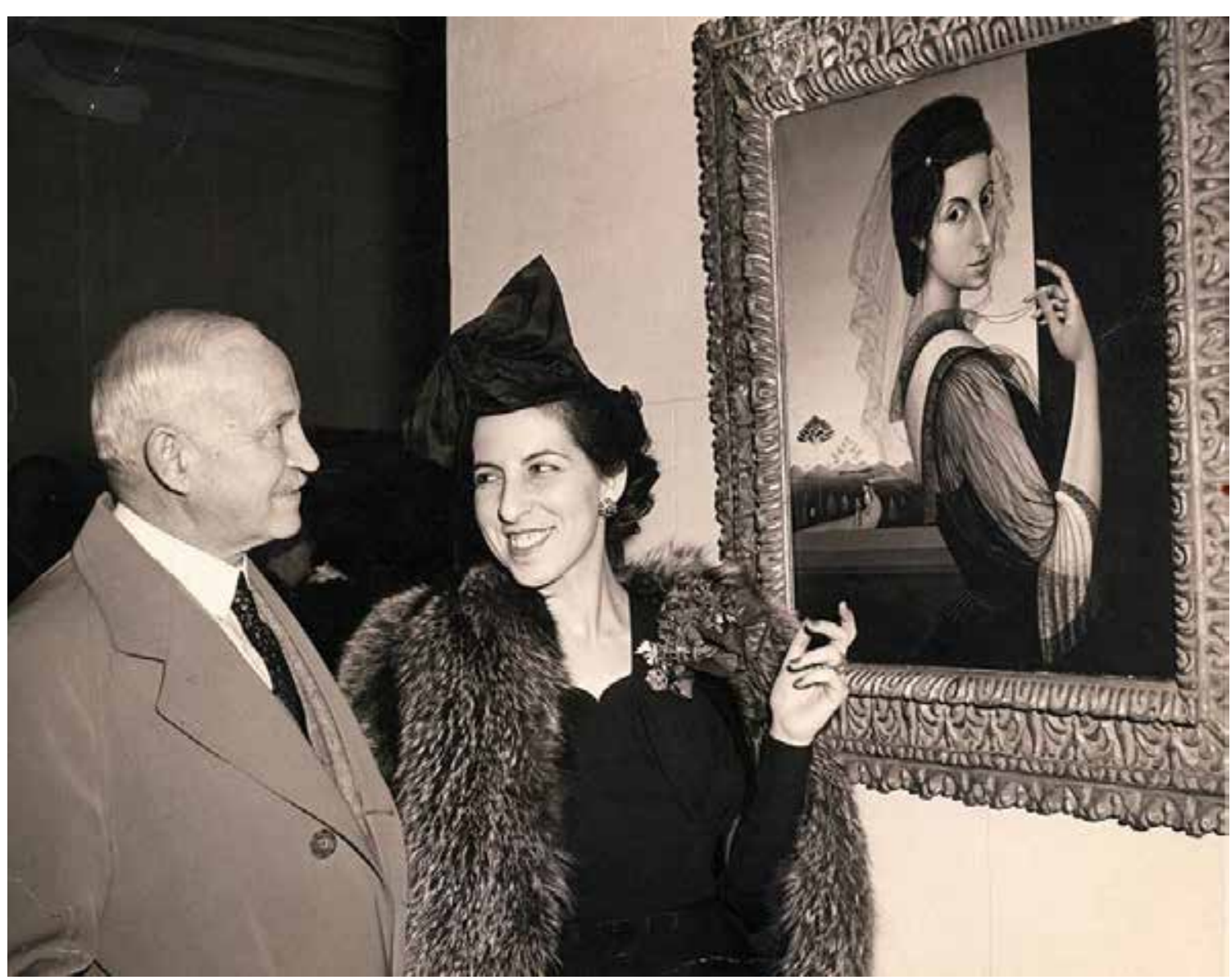

Fig. 3 Milena Pavlović Barilli at the opening of her exhibition in New York in 1943 (Galerija Milene Pavlović Barilli. "Galerija slika - porodične fotografije", http:/galerijamilenepavlovicbarilli.rs/galerija-slika/, accessed on December, 6th 2019).

the First World War, it did not function from 1915 to 1930 . During the 1930 s the museum activities were renewed. In 1947, the museum was opened in one of the city houses, while from 1951, the collections have been housed in the present-day museum building (Манојловић 1996, 9, 10, 30, 31; Драгојевић 1996, 41, 44).

Even if Milena did not have an opportunity to visit Viminacium, she probably had a chance to see the artefacts from the site within the previously mentioned private collections and the inventory of the Gymnasium. Milena was a student of the Gymnasium after the First World War (Protić 1979, 10), that is, during the period when the museum was closed, but she probably could see some ancient fragments left. She could also see the artefacts being sold in the antiquities markets in the Požarevac area, which was a common practice among the local population during the $19^{\text {th }}$ and $20^{\text {th }}$ century. Today, many artefacts from Viminacium are in some private or even museum collections around the world. Although it is hard to trace their exact routes it could be supposed that the closeness of Danube was important, especially during the $19^{\text {th }}$ and beginning of the $20^{\text {th }}$ century, as a fast connection with Central and Western Europe. At the same time, the young Milena with her family had begun her journeys from the Danube port in the nearby Dubravica village, ancient Margum. ${ }^{4}$

Everything mentioned above coincides with a source very important to this study. The source, which can be considered first-hand, is the last let-

4 About Požarevac and its vicinity and Milena's early life in: Bulajić 2010, 262-279. 


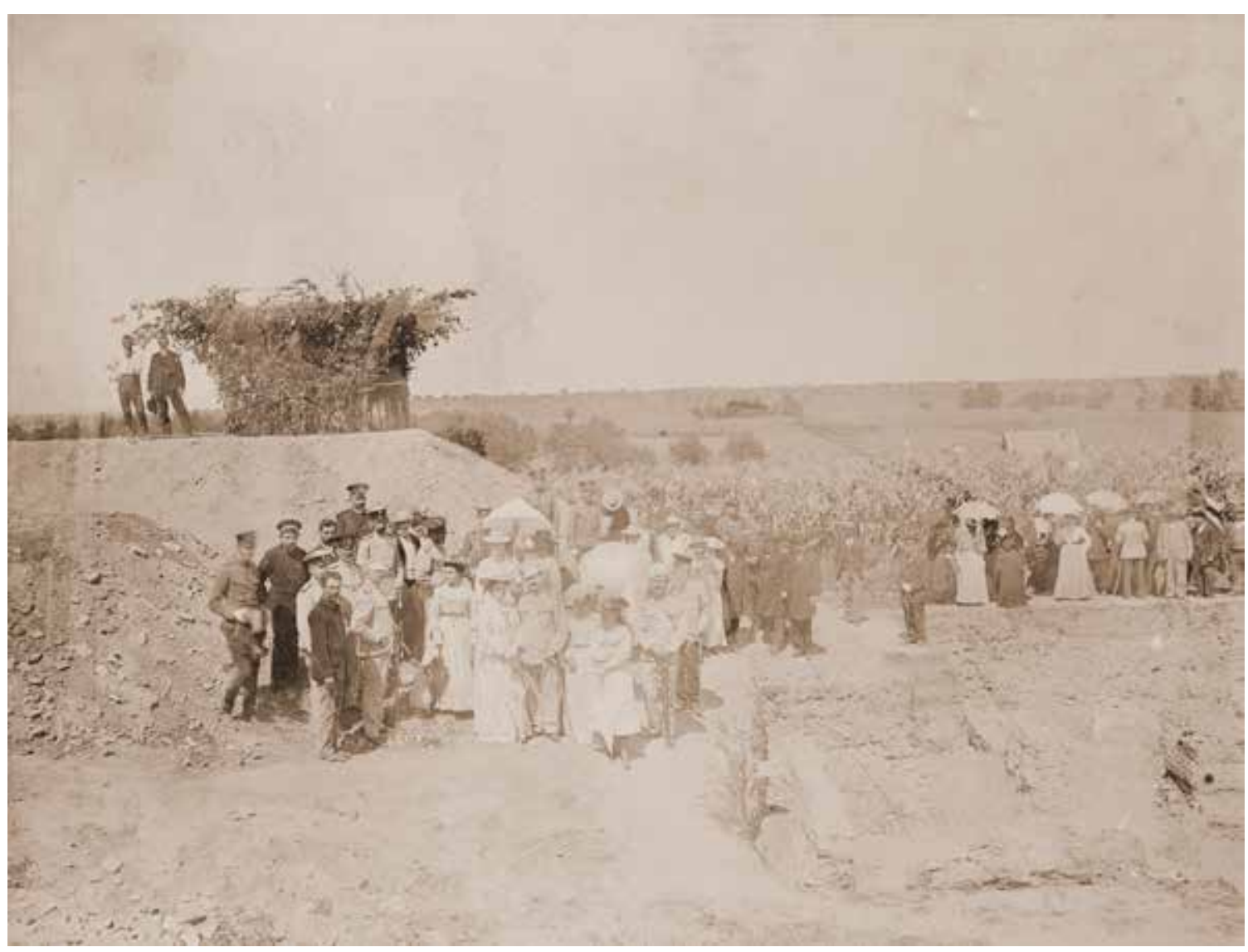

Fig. 4 King Aleksandar Obrenović and Queen Draga visiting Viminacium in 1902 (Спасић-Ђурић 2015, 16, Сл. 13)

ter that Milena sent to her mother in 1943, where she wrote: "My dear mum... The most beautiful sunset is in our garden in Požarevac. People think that only in past times did I look for patterns for my paintings, but they emerged from the freeze of my childhood days for grasses, clouds, birds, butterflies, for our fields and woodlands... In my imagination, our stories about forest fairies which you used to tell me came together with the poems of Valéry, and the broken Roman sculptures and sarcophagi, which I watched with enthusiasm and admiration in the archaeological sites near Požarevac, and led me to the visions of Botticelli and De Chirico" (Jovanović 2019). A similar observation was made by Miodrag B. Protić (19222014), the artist and art historian, who wrote, obviously influenced by the previous letter regarding the great influence on Milena's painting made by her personal experiences she gained in her home- town during childhood, namely the antiquities she saw. Protic wrote: "Childhood and youth in this landscape rich, among other, with the archaeological sites - broken Roman sculptures and sarcophagi - influenced Milena's sentimental education and prepared materials for the encyclopaedia of her artistic symbols" (Protić 1979, 16-17).

\section{ANCIENT ARCHITECTURAL AND SCULPTURAL ELEMENTS IN THE PAINTING OF MILENA PAVLOVIĆ BARILI}

The period between 1932 and 1936, Miodrag B. Protić referred to as Milena's "linear" or "Parisian and Roman" period and characterised it as the period when her poetic or magical relationism was formulated, which would be present as a base 


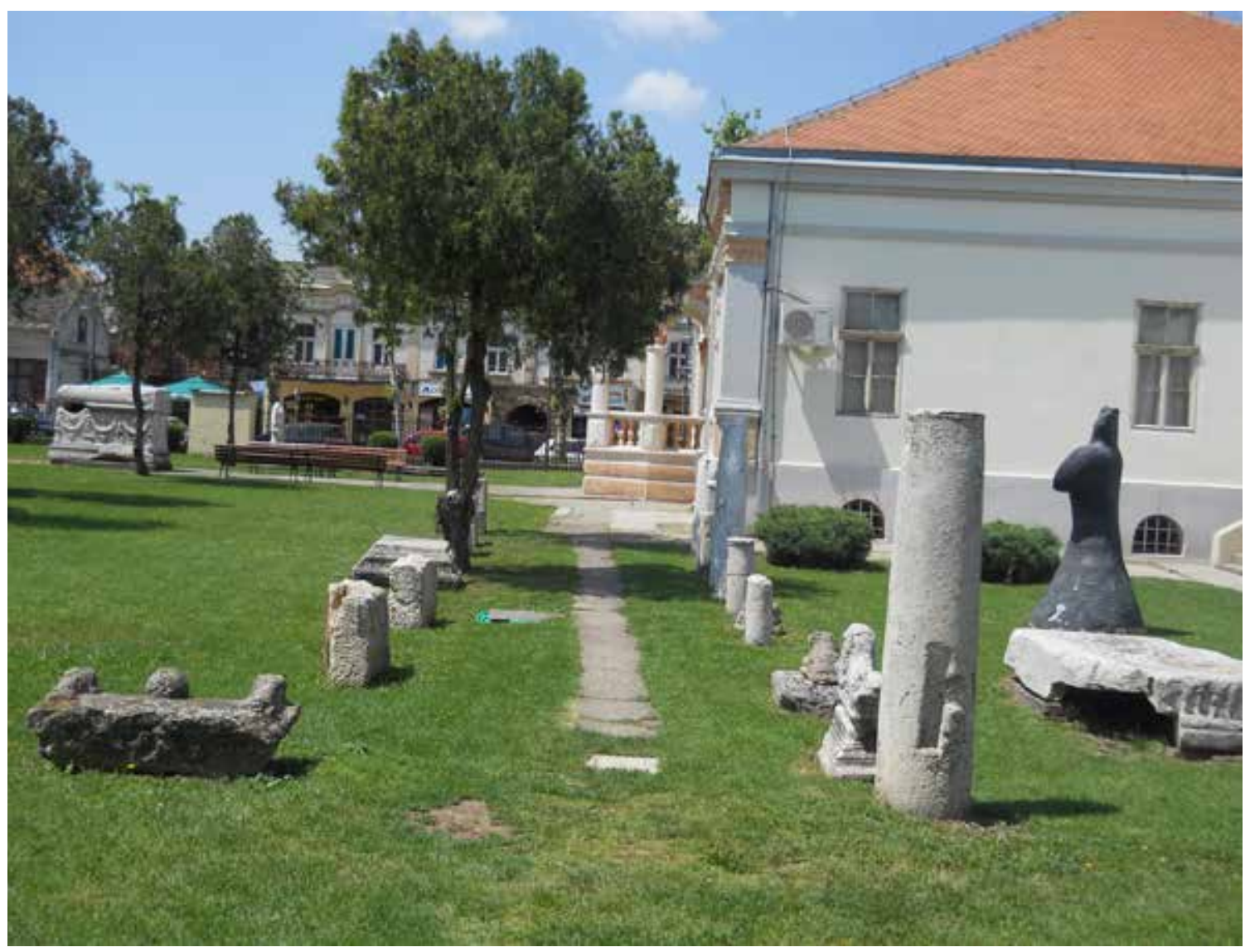

Fig. 5 National Museum in Požarevac and its lapidarium today (photo by Emilija Nikolić).

in all later phases of her work (Protić 1979, 7). Jelica Milojković called this period her "linear-ancient" period, describing it as a formed whole within which the irrational and fantastic enriched the iconography created by symbolic motifs and allegories, with the content and topic as the most important parts of the painting (Милојковић 2009, 49-90). During this period, a note of secret fiction is present in Milena's painting, as well as in the drawings named Surrealistic compositions or Surrealistic drawings. In this iconography, a disturbed relationship between objects is noticeable, and images are transferred from the realm of reality into the realm of dreams, hallucinations or enigmatic narratives, while in the artistic manner the line is dominant and used for the describing and creation of all forms (Protic 1979, 19). The linear phase of Milena's painting, rich in its use of antique motifs, framed within the mentioned years, is the period during which Milena often used to visit her mother in Požarevac. In 1936, Milena left Požarevac and never returned.

One can primarily try to trace the visible and material relationship between Viminacium and Milena's art in motifs that are associated with Antiquity. The architectural elements and fragments, statues or human figures that resemble statues, as well as compositions that refer to the mythological patterns are an indicative part of Milena's pictorial poetics. ${ }^{5}$ Within Milena's paintings in the technique of oil on canvas, human figures are often represented as statues, mostly torsoi. Male and female figures are equally represented, while androgyny is also present in several paintings. ${ }^{6}$

5 Since the legacy of Milena's art comprises more than 600 works of art, the paintings that are already well known and analysed by experts are used as reference examples in this paper.

6 On androgyny and emancipation in Milena's art see: 

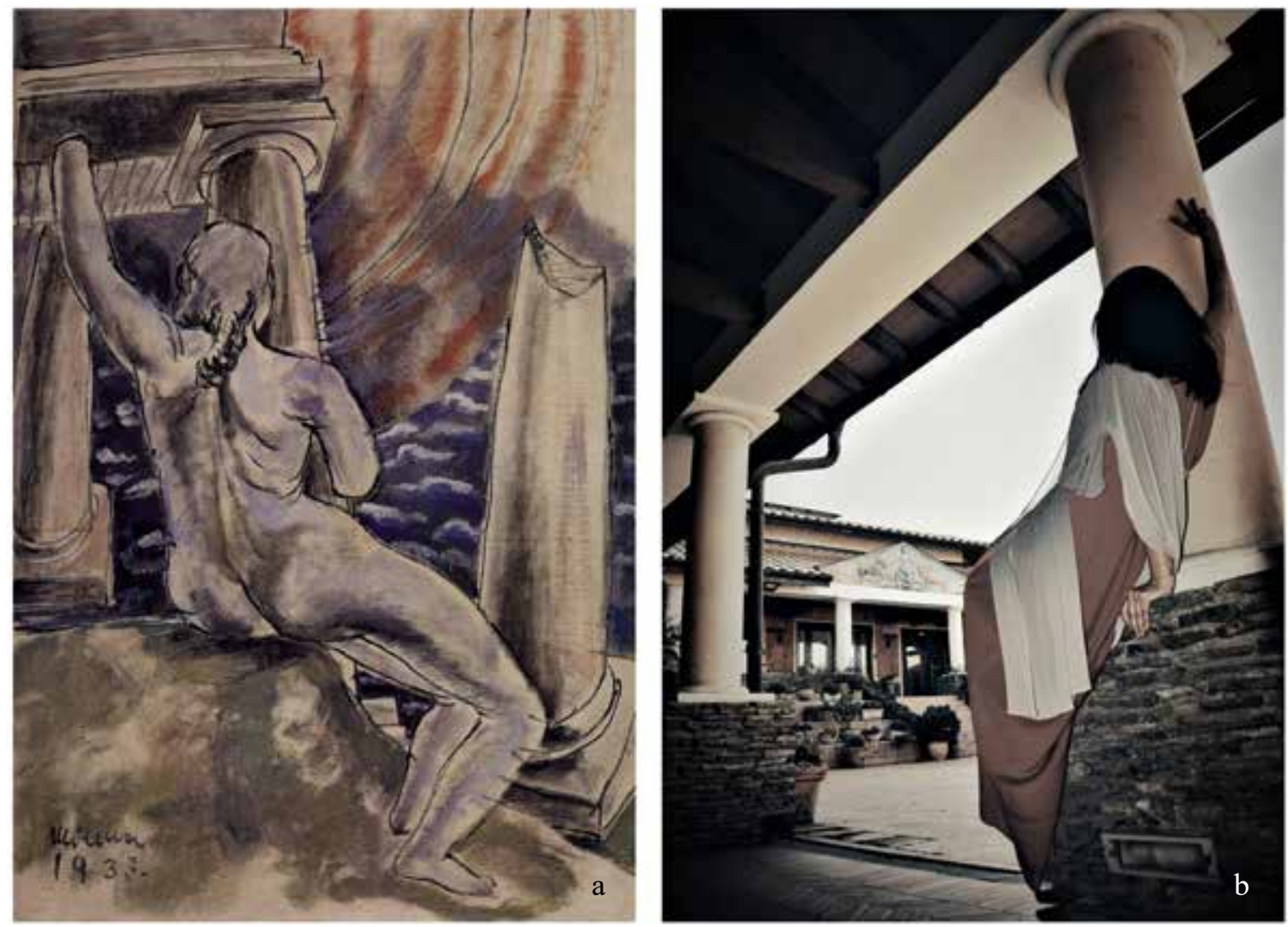

Fig. 6 a. Milena Pavlović Barilli: "Composition with a Female Fig. and Columns”, 1933 (reproduction from the Milena Pavlović Barilli Gallery); b. Subconscious mutual connection of the archetypes and unconscious acts, both well known in surrealism and recognized in the painting "Composition with a Female Fig. and Columns" can be also noticed in the ambient of the contemporary building in Viminacium Archaeological Park (photo by Nemanja Mrđić).

Wings are often painted instead of arms, while heads and faces are rendered more or less with a human look, but more often characterised with a sculptural modelling - an ancient one ("Torso with the Wing"/“Torzo sa krilom"; "Male Figure with Wings"/“Muška figura sa krilima"; "A Woman with Holey Leaf”/“Žena sa probušenim listom"; "Torso with a Black Hand"/“Torzo s crnom rukom"; "Composition with Hands"/“"Kompozicija sa rukama" - 1932; "Female Winged Torso"/“Ženski krilati torso"; "Composition with Two Figures"/“Kompozicija sa dva lika”; "A Black Woman with a Figure"/“Crna žena sa figurom"; "Female Bust"/“Žensko poprsje"; "Seminude and a Portrait"/“Poluakt i portret" - 1933; "A Portrait with a Black Glove"/“Portret sa crnom rukavicom"; "Self-Portrait as a Still Life"/“Au-

Janković 2010, 178-208. toportret kao mrtva priroda" - 1935; "A Doll (Composition with a Ball)"/“Lutka (kompozicija sa loptom)" - 1936). The whole female figure rendered in the manner of the ancient sculpture is noticeable in two paintings from 1933 - "Composition with a Female Figure and Columns"/“Kompozicija sa ženskom figurom i stubovima" (Fig. 6a) and "Composition with a Female Figure, a Column and a Tree"/“Kompozicija sa ženskom figurom, stubom i drvetom" (Fig.7a). In the last one, the female figure, based on the posture, resembles the Venus sculpture type, while the male bust possesses the solemnity and iconography of a Roman imperial bust, resembling the emperor Caracalla (Fig. 7b-7f), especially his bust from the National Archaeological Museum of Naples (211-217). It is hard to suppose that Milena was interested in the history of Viminacium's Legion 

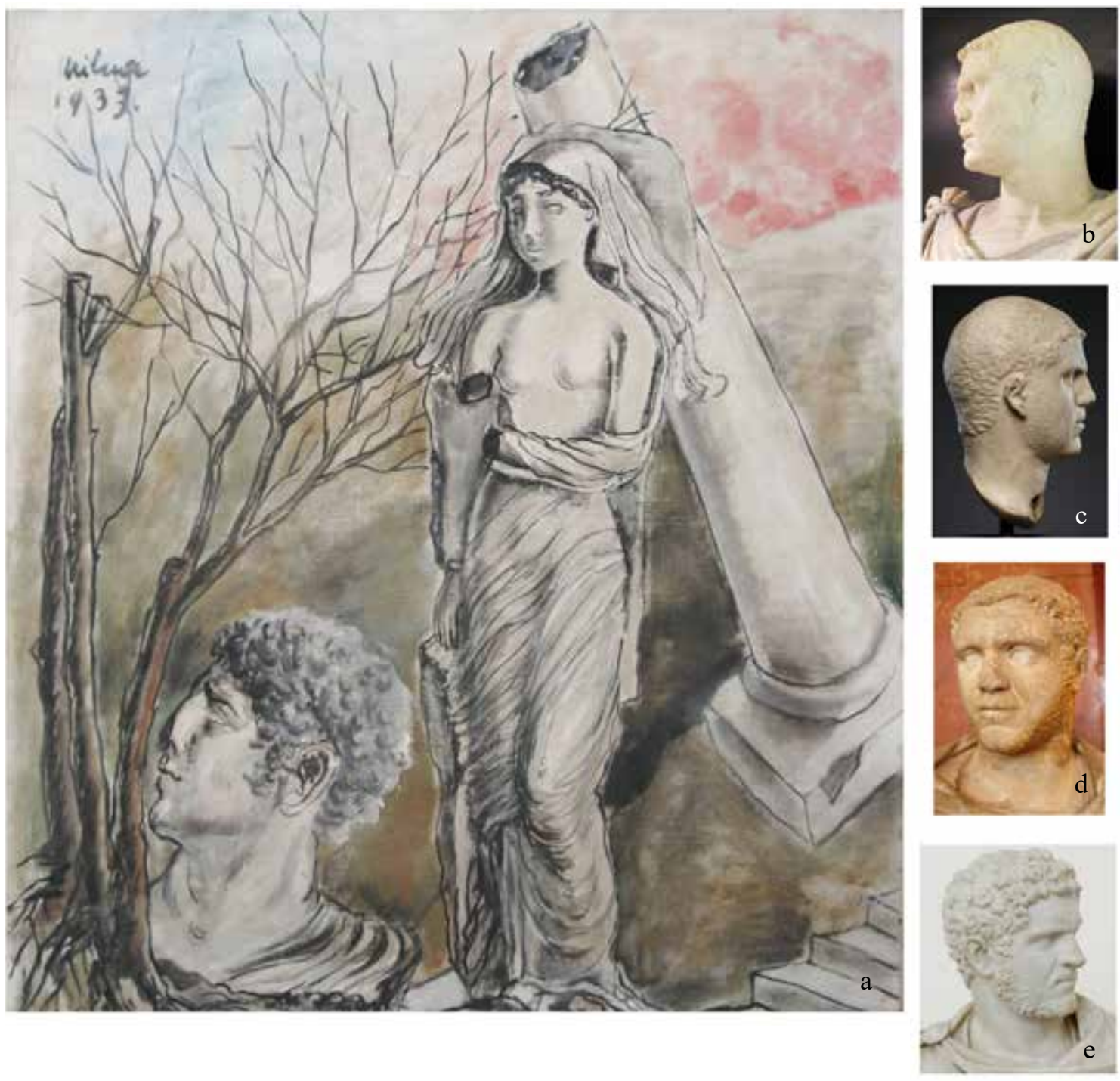

Fig. 7 a. Milena Pavlović Barilli: "Composition with a Female Fig., a Column and a Tree", 1933 (reproduction from the Milena Pavlović Barilli Gallery); Caracalla bust from: b. Museo dei Marmi, palazzo Medici-Riccardi, Firenze (Used and cropped by Emilija Nikolić (C) Sailko / Wikimedia Commons / CC BY-SA 3.0, https://commons.wikimedia.org/wiki/File:Arte_ romana,_busto_di_caracalla,_III_sec._ca._05.JPG, accessed on December, 6th 2019); c. Metropolitan Museum of Art (Used and cropped by Emilija Nikolić (C) Samuel D. Lee Fund, 1940 / Wikimedia Commons / CC0 1.0, https://commons.wikimedia.org/wiki/ File:Marble_portrait_of_the_emperor_Caracalla_MET_DP333082.jpg, accessed on December, 6th 2019); d. The Department of Greek, Etruscan and Roman antiquities, The Louvre, Paris (Used and cropped by Emilija Nikolić; Public auction Hirsh, 1957, Marie-Lan Nguyen (2005) / Wikimedia Commons / No license / https://commons.wikimedia.org/wiki/File:Caracalla_ Louvre.jpg, accessed on December, 6th 2019); e. Naples National Archaeological Museum, Naples (Used and cropped by Emilija Nikolić (C) Marie-Lan Nguyen (2011) / Wikimedia Commons / CC BY 2.5, https://commons.wikimedia.org/wiki/File:Caracalla_MAN_Napoli_ Inv6033_n06.jpg, accessed on December, 6th 2019); f. The British Museum, London (Used and cropped by Emilija Nikolić (C) Hyspaosines / Flickr / CC BY-SA 2.0, https://www.flickr. com/photos/12371736@N00/37023768113, accessed on December, 6th 2019); g. The Altes Museum, Berlin (Used and cropped by Emilija Nikolić (C) Hyspaosines / Flickr / CC BY-SA 2.0,
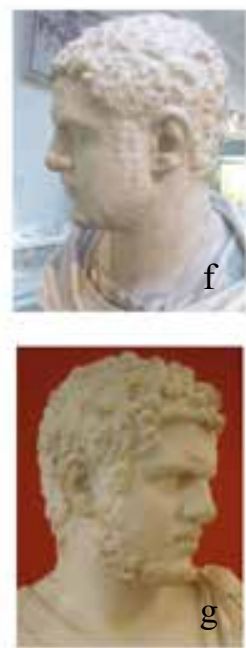
https://www.flickr.com/photos/12371736@N00/30182073661/in/album-72157634095284442/, accessed on December, 6th 2019). 
VII Claudia, which participated in military campaigns against the Parthians organised by the emperors Septimius Severus and Caracalla (СпасићЂурић 2015, 26), and the fact that Caracalla was proclaimed Caesar in Viminacium in 196 AD (Mócsy 2014, 201), but it would be possible to suggest the notion that the emperor's bust might once have existed among the lost treasures of Viminacium art that she was able to see.

Floating sculptural fragments, busts, torsi or arms belong to some petrified characters or revived ancient sculptures which, owing to their floating, lose the heaviness of material things and become disembodied. The diluted colours that she used in paintings ruin the well known visual features of the real world and, together with images of immobile characters or their metamorphoses - from living to petrified or dead, suggest the psychological reality that created them (Janković 2001, 34).

Columns are present in several of Milena's paintings as well. They usually unequivocally refer to Antiquity, resembling Greek and Roman architectural orders. In Greek and Roman architecture, Ionic order was considered female, while Doric was associate with the male gender. This can be considered an important part of the column symbolism together with its symbolism generally. Since the shaft of a Greek Doric column is always fluted and it has no base, and the bases of the Roman Doric and Tuscan order columns are differently shaped, according to the painted flat surface of the shaft and its base it can be assumed that the column depicted in the painting "Male Figure with Wings"/"Muška figura sa krilima" could belong to the more decorative Ionic, Corinthian or Composite order. However, the base mostly resembles a Roman Ionic base. Columns with capitals and bases resembling the less decorative Roman Doric or Tuscan order, broken or sometimes as part of architecture with architraves suggesting temples, are present in Milena's paintings as well, but combined with female figures ("Composition with a female figure and columns"/"Kompozicija sa ženskom figurom i stubovima" (Fig. 6a), "Com- position with a Female Figure, a Column and a Tree"/“Kompozicija sa ženskom figurom, stubom i drvetom" (Fig. 7a) - 1933, "La lettura" - 1935).

Usually, columns in Milena's works are painted without capitals. A column fracture can endanger the whole structure (architectural, social or personal), it is the connection between the sky and earth, while in Roman mythology it had a phallic significance in the cult of the goddess Ceres, symbolising fertility (Gerbran, Ševalije 2004, 889-894). Since the capital is considered the head of the column, beheaded columns together with statues can participate in the complicated narrative of Milena's fantasies, dreams, unconscious fears and questions regarding the unsettled relationships within her personal life. As Jelica Milojković wrote, a column is an element that gives life to the building it supports. Broken column shafts, without the capital or the base, "evoke the damaged power of life and creation, the absence of happiness and the impossibility of progress" (Милојковић 1992, 145).

"The Portrait of Reynold Gonzales", from 1933, represents a realistically portrayed man leaning on a column. The fallen column, whose shaft is visible together with other motifs among which is a sculptured male body similar to the ancient Apollo, can be analysed using phantasms and symbols of the unconscious, which create the image. The interpretation of the motifs in the painting named "A Doll" is associated with symbols of transformation and playing with the gender identities, while the column and the male figure are interpreted in the same manner corresponding with broken rules and stereotypes, as well as reinforcing the idea of the ambivalent relationship of the "male" and "female" positions (Јовичић и Башић 2015, 395-410). A column without a capital and with an architrave is painted as a background in the painting "Double Face"/“Dvostruki lik" from 1934, while a winged portrait and mask are depicted in the foreground (Fig. 8a). Olivera Janković described this composition as a continuation of the process of the metamorphosis of 

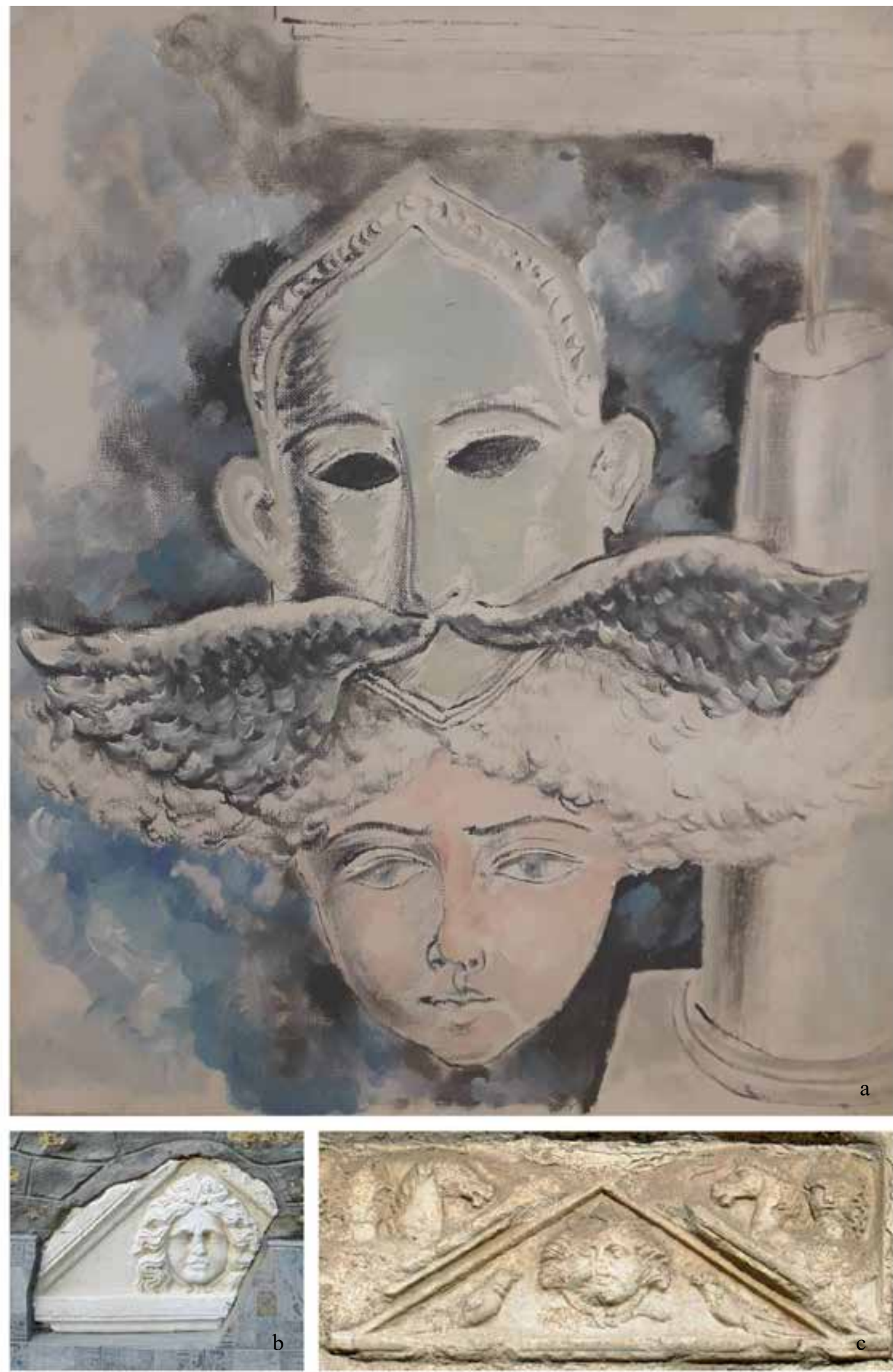

Fig. 8. a. Milena Pavlović Barilli: "Double Face”, 1934 (reproduction from the Milena Pavlović Barilli Gallery); b. Fragment with Medusa from the Nimnik monastery (Milovanović and Anđelković Grašar 2017, 117, Fig. 20); c. Fragment with Medusa from the Rukumija monastery (Milovanović and Anđelković Grašar 2017, 177, Fig. 19). 
the abstract mesh on the woman's head into an intimation of death and, in this specific example, transformed into a superior and rampant winged figure hovering over a frightened face, painted in the bluish tones of veins as a sign of the cheerless fate that has befallen it (Janković 2010, 170. cf. Protic 1979, 23). Although the author recognised the form of Medusa's face in the painting named "A Girl with a guitar"/“Devojka sa gitarom", in the painting "Double face" - where this reference can be used even more clearly, she did not mention such a connection. In the décor, inspired by Antiquity, in front of the ruined architecture and a blue, cloudy sky, ancient motifs are placed, with complex symbolical connotations. The dreamy face, with curly, dishevelled hair and wings on the top of the head unequivocally resemble the popular Roman Medusa image, while the mask like face above it can be associated with ancient warrior masks. In such a constellation it would be reasonable to suppose that this was Milena's personal interpretation of the myth of Medusa and the brave Perseus who killed the monster, since the artist was well educated, minded toward myth interpretations in her work and often inspired by popular ancient motifs. This interpretation of the depicted motifs can be built on the ever present dualism in Milena's art and, in this case, specifically the relationship between male and female, as well as questions of the gender roles within society, since the Medusa has always signified the wild female force, protective towards women and frightening to men, and which was finally defeated by the male strength of Perseus killing her (Milovanović and Anđelković Grašar 2017, 167-182).

Fragments of Roman monuments with representations of Medusa have been built into the walls of several historic buildings in the immediate and wider surroundings of Viminacium. The Church of the Assumption of the Blessed Virgin Mary in the Old Smederevo Cemetery is believed to have been built in the mid- $15^{\text {th }}$ century but has been restored several times since the beginning of the $18^{\text {th }}$ century, but the origin of the built-in fragment is unknown
(Цуњак 1984, 249, 257; Радовановић 1997, 248249; Цветковић 2009, 41-42). A tombstone called "The Return of Alkesta", built into the wall of the Smederevo fortress, from the mid- $15^{\text {th }}$ century, probably originates from Viminacium (Цветковић 2009, 36-37; Pilipović 2011, 598-599, 611). At two opposite ends of the plain of Stig, on which Viminacium was located, there are two monasteries, the monastery of Rukumija and the monastery of Nimnik, whose foundation is linked to Prince Lazar and the $14^{\text {th }}$ century, and reconstruction to Prince Miloš and the $19^{\text {th }}$ century (Бојковић и Ђокић 2016,88 , $90,99,104)$. The fragment embedded in the church of St. Nicholas of the Nimnik Monastery (Fig. 8b) probably originates from one of the settlements that belonged to Viminacium territorially and administratively (Спасић 1998, 316, 318), while the fragment embedded in the wall of the Church of the Holy Ascension of the Rukumija Monastery (Fig. 8c) is assumed to have originated from Viminacium itself (Спасић 1996, 222). The embedded fragments in these two churches are very important elements of the oral intangible heritage of the Viminacium area, as the characters of Medusa were interpreted as personifications of female characters of folk songs and traditions (Радовановић 1997, 238; Milovanović and Anđelković Grašar 2017, 176-177; Бојковић и Ђокић 2016, 90). It is interesting to mention here that the largest number of Roman tombstones found in the territory of the former Province of Upper Moesia, with a tympanum, have a rosette in the middle, while the next motif by number is the head of Medusa, and all the monuments found with this motif come from Viminacium (Pilipović 2004, 362):

Some of Milena's compositions are interpreted according to a surrealistic ideology and her pictorial poetics. In such a way, the connection between the small watercolour on paper "Vase with Carnations"/"Vaza sa karanfilima" (Fig. 9a) and the painting "Winged Anthropomorphic Vase"/"Krilata antropomorfna vaza" (Fig. 9b), both from 1935, is described by Olivera Janković with a homonym - a stylistic device that includes 

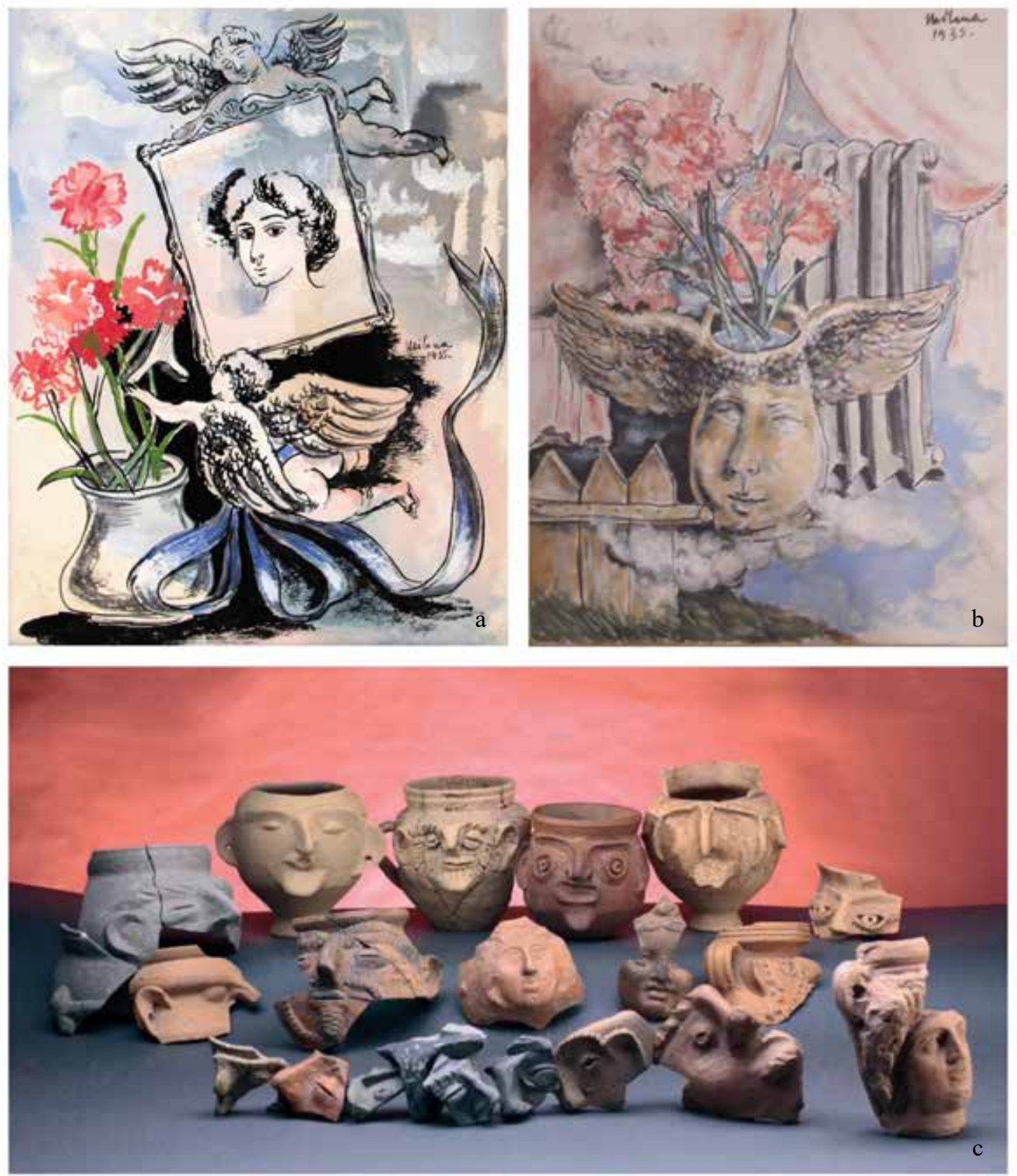

Fig. 9. a. Milena Pavlović Barilli: "Vase with Carnations", 1935 (reproduction from the Milena Pavlović Barilli Gallery); b. Milena Pavlović Barilli: "Winged Anthropomorphic Vase", 1935 (reproduction from the Milena Pavlović Barilli Gallery); c. Prosopomorphic Vessels from Moesia Superior (Nikolić and Raičković 2008, 139, Fig. 2).

the same forms with different meanings and allows seemingly absurd combinations or metamorphoses of objects (Janković 2010, 174. cf. Protić 1979, 23). Analysing the two compositions she wrote: "In the former, two little angles are taking away a framed photograph of the artist, a realistic self-portrait of Milena Pavlović Barilli, while in the latter, a less significant detail in this work, a vase with carnations, which stands next to the photo, is transformed into a key figure, that is, into the form of a human face with added wings with which it flies like a cherub... Taken together, these two works show how one picture becomes an impulse for the creation of another, or indicates the 


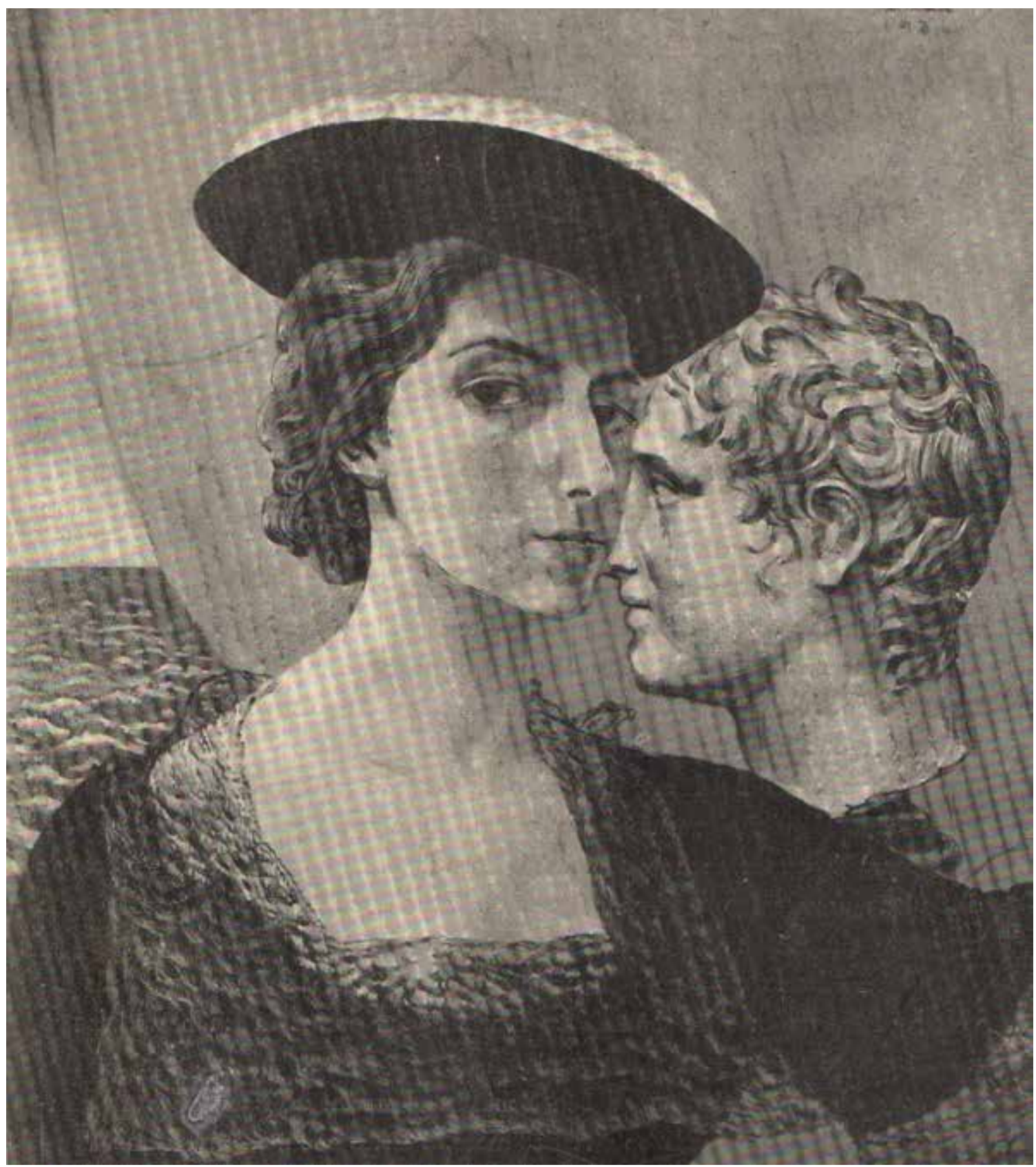

Fig. 10. Milena Pavlović Barilli: "Self-portrait with Antiquity Head", 1936 (reproduction from the Milena Pavlović Barilli Gallery).

process of an imaginary migration of signs from one work to another in accordance with free associations" (Janković 2010, 174, 176). The last sentence and the idea of the impulse for the creation or imaginary migration of signs stands correctly, but allows the further interpretation of migrating signs and impulses, especially knowing that Milena possessed a knowledge of art history, visited international museums and had an opportunity to be in live contact with the archaeological heritage in the vicinity of her hometown.

The compositional structure of the watercolour work "Vase with Carnations" can be associated with the ancient composition known as imago clipeata, usually represented on Roman sarcophagi, when a portrait of the deceased is depicted in a 
framed field, often flanked by the image of small winged boys - not angels, but Cupids. The motif of the anthropomorphic vase from the painting "Winged Anthropomorphic Vase" is not so surrealistic if we look back to Roman pottery production from the territory of Moesia Superior, and see that the largest number of this type of "vessel with a face" has been discovered at Viminacium (Nikolić and Raičković 2008, 136) (Fig. 9c). Thus, the motif itself does not necessarily have to be interpreted as Milena's vision, while the added wings and the ambient of the painting refer to the artist's well known pictorial poetics. The modern staging as a reinterpretation of the ancient imago clipeata and the ancient artefact of a prosopomorphic vessel that flies over time and space make the conclusion given by Olivera Janković universal, no matter what the correct interpretation of the symbols is: "Using the experience of what was seen before, intuited or recorded in another picture or another medium represented the means used in this art to represent the uncertainty of scenes seen in the mind's eye, which, at the very next moment, under the influence of a new element that enters the mind's field of vision, transforms into something else." (Janković 2010, 176)

Finally, it should be mentioned that Milena's poetry can be considered an echo and a source of the symbols she used in her painting (Pešikan-Ljuštanović 2010，242). Few of her poems mention architecture, statues or Antiquity generally. However, some associations can be found in her Italian poems, where she wrote on marble caryatides, columns and arches.

\section{SURREALISM: A METHOD FOR THE ASSOCIATION BETWEEN MILENA AND THE LANDSCAPE}

As a cultural movement, surrealism originates from the curative mechanisms used in psychoanalysis. It is based on the subconscious, stimulating the inner experiences. Surrealism as a super reality i.e. absolute reality, is based on the contradictory conditions of dream and reality, defined as pure psychic automatism by André Breton in his Surrealist Manifesto from 1924 (Breton 1961). Surrealistic paintings do not represent the real world visible to the eye, but the inner reality, dreams and mind of the artist (Waldberg 1970, 5-7). The movement was revolutionary in art and, from the 1920s onwards, it became globally recognised. Based on the inner being and experiences that originate from the real world, dreams and memories shaped in the unique mind of an individual artist, surrealism can be used as a method to connect the pictorial poetics of Milena Pavlović Barilli and the Viminacium landscape.

Various realistic objects were an important part of surrealistic compositions, but without a real and accurate context. These objects could have referred to psychological associations or even collective subconscious archetypes. These subconscious associations between realistic objects and spaces provide surrealistic compositions with symbolical and mystic meanings, as well as dream-narratives that highlight the presence of the otherness (Aspley 19-24). Based on the surrealistic ideology, it can be said that Milena's fascination with Antiquity and the use of ancient poetics during the "linear phase" of her work had its echo in the personal subconscious filled with the realistic, physical stimulations she had encountered in her childhood. Additionally, some ancient objects and interpretations of the antique heritage refer to the collective subconscious and archetypes which Milena used to reinforce the symbolical significance of her compositions.

It is also known that besides surrealism, the great influence in Milena's painting was Giorgio de Chirico (1888 - 1978), who founded Metaphysical art in 1911, which, in turn, influenced the formation of surrealism. Metaphysics does not rely upon real world experiences, but is more about the core of the world, which is beyond the real. In de Chirico's paintings, empty streets of Italian towns are combined with antique statues or Roman mythology, 
together with objects of everyday life. These enigmatic compositions can be understood only spiritually and be experienced only ingeniously (Calvesi 2006, 29-34). The same could be said about the comprehension of Milena's painting, which her intimate world brought to light owing to the mysterious and symbolical compositions created with ancient motifs, objects of everyday life, portraits and self-portraits within the interior and exterior of her life spaces. To understand Milena's art, a grasp of the symbols, signs, enigmas and metaphors is crucial, but only combined with her biography (Subotić 2010b, 40, with ref. 37). The strongest association between Milena's and de Chirico's art can be found in the combination of self-portraits and ancient portrait heads. "Self-Portrait with Antiquity Head" from 1936 (Fig. 10), concludes the linear period, but did not break with Antiquity as a source for its inspiration. It is based upon the methodology of producing a work from other works, where nothing other than remembrance can be created (Merenik 2009, 26-32).

\section{CONCLUSION}

The art of Milena Pavlović Barilli was deeply self-reflective, confessional and melancholic, in the spirit of post-metaphysical art, filled with symbols and metaphors, poetics and narration with reminiscences of Antiquity and the Renaissance - in which the achievements of Antiquity were praised as the peak of human art (Subotić 2010a, 286). Her paintings represent fragments of her personal experiences, transposed owing to the archaic-ancient motifs and united with the artistic imagination into a visual narrative, pointing toward the creation of a new vision of reality. The artist's creativity united the external and internal, dream and reality, past and future, intimate and the universally human (Јовичић и Башић 2015, 395-410). Among other features that shaped her personality and art were nomadism, interdisciplinarity, transnationality, as well as a specific return to some of the values of traditional art (Janković 2001, 6, 8).

Although Milena spent most of her life travelling the world, and was often considered a nomad, it seemed that her childhood and stay in her family house in Požarevac was an important part of her life and work, noted in her letters, poetry and paintings in the form of an elusive and unfulfilled dream of her home. ${ }^{7}$ This combination of global traveller, nomad and sentimental dreamer traditionally linked with the family, allowed Milena to create her individual pictorial poetics that rested upon the ideology of surrealism and metaphysical art. It is certain that the works of the old masters whose creations she had the chance to see during her visits or stays in several European and American artistic centres, together with the personal experiences she gained in her childhood, contributed to her specific poetics (Subotić 2000, 27-37; Subotić 2010b, 7-54).

An alternative interpretation of some of the motifs in Milena's compositions, which is based on knowledge of ancient iconography and symbolism, led the authors of this paper to the assumption that, subconsciously, ancient artefacts that Milena saw in her childhood and youth, quite possibly from Viminacium, were a very important part of her pictorial poetics in the latter years of her work. The authors wished to link the wider meaning of the term of Antiquity with the landscape of ancient Viminacium and suggest that, based on surrealistic ideology, Milena's strong love for her home town and its rich archaeological heritage or even some specific motifs in her art, show that this kind of association could be considered. The first researcher of Milena's art, the person who recognised the potential of her legacy and the one who helped Milena's mother open the legacy gallery in Požarevac in 1962, was Miodrag B. Protić. In his book (i.e. catalogue of an exhibition) dedicated to Milena, Protić wrote that her art was an inseparable part of her homeland legacy and, among other influences on her painting, as was written before, he mentioned the archaeological sites in the vicinity of Požarevac, dealing with

7 Janković 2001, 111. On Milena's nomadism and various identities in: Bakić 2010, 300-317. 
the details from the last letter she sent to her mother. His association should also be taken as relevant because of the fact that he spent significant time with Milena's mother Danica, discussing and interpreting Milena's work and life. ${ }^{8}$ Olivera Janković considered the Viminacium monuments a potential "ancient" inspiration for Milena, together with the vast cultural heritage of Rome, as well as artistic models during her education in Europe, concluding that by painting the sculptural and column remains, symbolical body analogies and previous events, "an artist acts as an archaeologist or philologist, who is trying, based on the traces of living, and the remains of some everyday life, to reconstruct forever lost artwork or an unknown world." (Janković 2001, 38). However, as Jelica Milojković wrote, Milena's symbols have "the suggestive and evocative power", can "widen the aspects of our previous knowledge", "revive the imagination" and "encourage us to further thinking." (Милојковић $1992,41)$. From these reasons, it is very important to state at the end of this paper that all the assumptions given in it are only possible meanings of Milena's art. Her paintings provide the researchers in art, archaeology or architecture with an immense amount of inspiration for the work, whose results offer the most precious conclusions when sublimated into joint research.

\section{ACKNOWLEDGEMENTS:}

The authors of the paper are grateful to the Milena Pavlović Barilli Gallery in Požarevac for the reproductions of Milena's works and permission to publish them. Special gratitude is owed to Violeta Tomić, the Gallery's curator, for the productive collaboration and unselfish help, as well as Jelica Milojković, Professor Simona Čupić, Dragan Jacanović and Dragana Spasić-Đurić for their valuable advice on the analyses and conclusions given in the paper. The authors would also

8 About Milena's life, according to Danica's writings, in: Tomić 2019: in print. like to thank their dear colleague Nemanja Mrđić and Dragana Pavlović for the creation of the photograph in the Viminacium Archaeological Park that is used in this paper.

$* * *$

Arheologija i prirodne nauke (Archaeology and Science) is an Open Access Journal. All articles can be downloaded free of charge and used in accordance with the licence Creative Commons - Attribution-NonCommercial-NoDerivs 3.0 Serbia (https://creativecommons.org/licenses/bync-nd/3.0/rs/.

Časopis Arheologija i prirodne nauke je dostupan u režimu otvorenog pristupa. Članci objavljeni u časopisu mogu se besplatno preuzeti sa sajta i koristiti u skladu sa licencom Creative Commons - Autorstvo-Nekomercijalno-Bez prerada 3.0 Srbija (https://creativecommons.org/licenses/bync-nd/3.0/rs/.

\section{BIBLIOGRAPHY}

\section{Anđelković Grašar, J. Rogić, D. and Nikolić E. 2013}

Viminacium, Archaeological Park - Modern Code for Re-Reading the Past of the Roman City and Legionary Camp, in: J. Popielska-Grzybowska, J. Iwaszczuk (Eds.): Studies on Disasters, Catastrophes and the Ends of the World in Sources, Acta Archaeologica Pultuskiensia vol. IV, The Pultusk Academy of Humanities, Pułtusk: 9-14.

\section{Aspley, K. 2010}

Historical Dictionary of Surrealism, Scarecrow Press, Lanham, Toronto, Plymouth UK.

\section{Bakić, J. 2010}

Changable Identities: The Change that Comes with Years, in: Milena Pavlović Barilli Vero Verius, Vreme, Život, Delo (ed. Z. Stablović Bulajić), HESPERIAedu, Beograd: 300-317. 


\section{Beazley, O. 2004}

Inspirational Landscapes as World Heritage: Problems of Identification and Management, in: Proceedings of 7th US/ICOMOS International Symposium, Natchitoches, Louisiana, USA: 1-14.

Бојковић, Г. и Ђокић, Н. 2016

Средњовековне иркве и манастири у Браничеву по српским и аустријским пописима из XVIII века. Пожаревац, Народни музеј Пожаревац. (Bojković, G. i Đokić, N. 2016

Srednjovekovne crkve $i$ manastiri u Braničevu po srpskim i austrijskim popisima iz XVIII veka. Požarevac, Narodni muzej Požarevac.)

\section{Breton, A. 1961}

Manifest nadrealizma (1924), Bagdala, Kruševac.

\section{Brown, S. 2008}

Integrating Cultural Landscape Approaches in Cultural Heritage Impact Assessment, Paper presented at IAIA08 Conference Proceedings', the Art and Science of Impact Assessment 28th Annual Conference of the International Association for Impact Assessment, 4-10 May 2008, Perth Convention Exhibition Centre, Perth, Australia.

\section{Bulajić, J. 2010}

Fragments from Požarevac, the Fate of the Pavlovic House, in: Milena Pavlović Barilli Vero Verius, Vreme, Život, Delo (ed. Z. Stablović Bulajić), HESPERIAedu, Beograd: 262-279.

\section{Calvesi, M. 2006}

Giorgio de Chirico and "Continuous Metaphisics", Metafisica 5/6: 29-34.

\section{Context Pty Ltd 2003}

Context Pty Ltd., Inspirational Landscapes Volume 4: Assessment Method Report.

\section{Цуњак, М. 1984}

Ископавање унутрашњег простора старе цркве у Смедереву, Саопитењ а XVI: 249-257.
(Cunjak, M. 1984

Iskopavanje unutrašnjeg prostora stare crkve y Smederevu, Saopštenja XVI: 249-257.)

\section{Цветковић, С.2009}

Античка пластика Смедеревске тврђаве - преглед досадашњих истраживања, Смедеревски зборник 2/2009: 29-43.

(Cvetković, S.2009

Antička plastika Smederevske tvrđave - pregled dosadašnjih istraživanja, Smederevski zbornik 2/2009: 29-43.)

\section{Deacon, H. and Beazley, O. 2007}

Safeguarding Intangible Heritage Values under the World Heritage Convention: Auschwitz, Hiroshima and Robben Island, in: Safeguarding Intangible Cultural Heritage - Challenges and Approaches (ed. J. Blake), Institute of Art and Law, Crickadarn: 93-108.

\section{Драгојевић, Ч. 1996}

Градски Народни музеј 1946-1954. године, in: Народни музеј Пожареваи 1896-1996 (ed. М. Манојловић), Народни музеј Пожаревац, Пожаревац, 41-46.

(Dragojević, Č. 1996

Gradski Narodni muzej 1946-1954. godine, in: Narodni muzej Požarevac 1896-1996 (ed. M. Manojlović), Narodni muzej Požarevac, Požarevac, 41-46.)

\section{Gallery, 2019}

Galerija Milene Pavlović Barilli, "Istorijat", http://galerijamilenepavlovicbarilli.rs/istorijat/, accessed on December, $6^{\text {th }} 2019$

\section{Gerbran, A. and Ševalije, Ž. 2004}

Rečnik simbola, Stylos, Novi Sad (1969).

\section{Golubović, S. and Korać, M. 2013}

Bringing to Life the Ancient City of Viminacium on the Danube, in: Presenting the Romans: Interpreting the Frontiers of the Roman Empire 
World Heritage Site (ed. N. Mills), Boydell Press, Woodbridge: 65-73.

\section{ICOMOS, 1995}

ICOMOS/World Heritage, A Report by Australia ICOMOS to the World Heritage Co,mmittee, The Asia-Pacific Regional Workshop on Associative Cultural Landscapes: "Where the Physical and Spiritual Unite”, Carmen Anon Feliu, Icomos, Sydney.

ICOMOS-IFLA, 2017

ICOMOS-IFLA, The Aesthetic Value of Landscapes Background and Assessment Guide: Technical Paper Number 2.

Janković, O. 2001

Milena Pavlović Barili, Fondacija Milenin dom Galerija Milene Pavlović Barilli, Požarevac.

\section{Janković, O. 2010}

The Metamorphoses of Milena Pavlović Barilli, Between "Pure" and Applied Art, in: Milena Pavlović Barilli Vero Verius, vreme, život, delo (ed. Z. Stablović Bulajić), HESPERIAedu, Beograd: 122-209.

\section{Jovanovic, N. 2019}

Sve je u Mileninom životu izuzetno, Erudita, 21.11.2019, https://www.erudita.rs/kultura-i-istorija/milena-pavlovic-barili/, accessed on December, $6^{\text {th }} 2019$

\section{Јовичић, П. и Башић, И. 2015}

Маске и метаморфозе женске креативности - Лутка Милене Павловић Барили, Гласник Етнографског института САНУ 63/2: 395410.

(Jovičić, P. i Bašić, I. 2015

Maske i metamorfoze ženske kreativnosti - Lutka Milene Pavlović Barili, Glasnik Etnografskog instituta SANU 63/2: 395-410.)

\section{Каниц, Ф. 1989}

Србија: Земьа и становништво од римског доба до краја XIX века, прва књига, Српска књижевна задруга, Београд.

(Kanic, F. 1989

Srbija: Zemlja i stanovništvo od rimskog doba do kraja XIX veka, prva knjiga, Srpska književna zadruga, Beograd.)

\section{Knap, B. A. and Ashmore, W. 1999}

Archaeological Landscapes: Constructed, Conceptualized, Ideational, in: Archaeologies of Landscape: Contemporary Perspectives (eds. W.Ashmore, A.B.Knapp), Wiley-Blackwell Publishers, Oxford: 1-30.

\section{Korać, M. and Golubović, S. 2009}

Viminacium. Više grobalja, tom 2, Archaeological Institute Belgrade, Belgrade.

\section{Манојловић, М. 1996}

Сто година од оснивања Народног музеја у Пожаревцу, in: Народни музеј Пожареваи 1896-1996 (ed. М. Манојловић), Народни музеј Пожаревац, Пожаревац, 5-39.

(Manojlović, M. 1996

Sto godina od osnivanja Narodnog muzeja u Požarevcu, in: Narodni muzej Požarevac 18961996 (ed. M. Manojlović), Narodni muzej Požarevac, Požarevac, 5-39.)

\section{Merenik, L. 2009}

The portrait of a Lady, in: Milena Pavlović Barilli Ex Post, Kritike, članci, bibliografija, (ed. Z. Stablović Bulajić), HESPERIAedu, Beograd: 7-65.

\section{Миленковић, М. и Протић, Ж. 1936}

Природне лепоте и богатство Поморавља, Стига, Браничева, Звижда и Хомоља, Удружење Пожаревљана, Београд.

(Milenković, M. i Protić, Ž. 1936

Prirodne lepote $i$ bogatstvo Pomoravlja, Stiga, Braničeva, Zvižda i Homolja, Udruženje Požarevljana, Beograd.) 
Милојковић, J. 1992

Симболички мотиви у уметничком делу

Милене Павловић-Barilli, Viminacivm 7: 141164.

(Milojković, J. 1992

Simbolički motivi u umetničkom delu Milene

Pavlović-Barilli, Viminacivm 7: 141-164.)

Милојковић, J. 2009

Звезданим трагом Милена Павловић-Barilli (Пожареваи, 1909-Њујорк, 1945), Галерија САНУ Београд, 17. Јули - 25. Август 2009, Фондација Миленинин дом, Пожаревац.

(Milojković, J. 2009

Zvezdanim tragom Milena Pavlović-Barilli (Požarevac, 1909-Njujork, 1945), Galerija SANU Beograd, 17. Juli - 25. Avgust 2009, Fondacija Mileninin dom, Požarevac. )

Milovanović, B. and Anđelković Grašar, J. 2017

Female Power that Protects: Examples of the Apotropaic and Decorative Functions of the Medusa in Roman Visual Culture from the Territory of the Central Balkans, Starinar 67: 167-182.

\section{Mócsy, A. 2014}

Pannonia and Upper Moesia (Routledge Revivals): a History of the Middle Danube Provinces of the Roman Empire (1974), Taylor and Francis, Abingdon and New York.

Nikolić, E., Anđelković Grašar, J. and Rogić, D. 2017

Viminacium: Research, Protection and Recognition, in: Preserving transcultural heritage: your way or my way? (ed. J.R. dos Santos), ARTIS Institute of Art History from School of Arts and Humanities of the University of Lisbon and the ICOMOS Portugal, Lisbon: 574-583.

\section{Nikolić, E., Ilić, O. and Rogić, D. 2013}

Possibilities of Defining the Archaeological Site of Viminacium as a Unique Cultural Landscape, in: Strategie e Programmazione della Conservazione e Trasmissibilità del Patrimonio Culturale, (eds. A. Filipovic W.Troiano), Edizioni Scientifiche Fidei Signa, Roma: 260-271.

Nikolić, E. and Roter-Blagojević, M. 2017

A New Dialogue Between Past and Future - the Archaeological Site Viminacium within the New National and International Frameworks, in: $19^{\text {th }} I n$ ternational Conference and General Assembly of the Experts Fondazione Romualdo Del Bianco ${ }^{\circledR}$ - Life beyond Tourism ${ }^{\circledR}$ : HERITAGE for PLANET EARTH® 2017: Smart Travel, Smart Architecture, Heritage and its Enjoyment for Dialogue - Proceedings (ed. C. Del Bianco), Masso delle Fate Edizioni, Florence: 188-204.

\section{Nikolić, E. and Roter-Blagojević, M. 2018}

Cultural Landscape of Ancient Viminacium and Modern Kostolac - Creation of a New Approach to the Preservation and Presentation of its Archaeological and Industrial Heritage, in: Conference Proceedings. 5th International Academic Conference on Places and Technologies 2018 (eds. A. Krstić - Furundžić et al.) Faculty of Architecture, University of Belgrade, Belgrade: 785-792.

\section{Nikolić, S. and Raičković, A. 2008}

Prosopomorphic Vessels from Moesia Superior, Starinar 58: 135-153.

\section{Pešikan-Ljuštanović, Lj. 2010}

Under the Light of a Burnt Moon, The Shaping of Space in Milena Pavlović Barilli's Poetry, in: Milena Pavlović Barilli Vero Verius, Vreme, Život, Delo (ed. Z. Stablović Bulajić), HESPERIAedu, Beograd: 210-243.

\section{Pilipović, S. 2004}

Dolphin Representations on Stelae from Upper Moesia, Balcanica XXXIV: 357-383.

\section{Pilipović, S. 2011}

Un gruppo di stele funerarie provenienti da Vimi- 
nacium (Moesia Superiore), Classica et Christiana 6/2: 593-612.

\section{Protić, M. B. 1979}

Milena Pavlović-Barili: retrospektivna izložba 1926-1945: Muzej savremene umetnosti, Beograd oktobar-decembar 1979, Muzej Savremene umetnosti, Beograd.

\section{Радовановић, Д. 1997}

Радовановић, Археолошка налазишта са сакралним садржајем на подручју Подунавског и Браничевског округа, in: Споменици Смедеревља и Браничева 1 (ed. Н. Јоцовић), Регионални завод за заштиту споменика културе Смедерево, Смедерево: 235-256.

(Radovanović, D. 1997

Radovanović, Arheološka nalazišta sa sakralnim sadržajem na području Podunavskog i Braničevskog okruga, in: Spomenici Smederevlja i Braničeva 1 (ed. N. Jocović), Regionalni zavod za zaštitu spomenika kulture Smederevo, Smederevo: 235-256.)

\section{Сариа, Б. 1934}

Сариа, Један надгробни споменик из Виминација, Старинар VIII-IX/1933- 1934: 73-83.

(Saria, B. 1934

Saria, Jedan nadgrobni spomenik iz Viminacija, Starinar VIII-IX/1933- 1934: 73-83.)

\section{Спасић, Д. 1996}

Пример археолошког трага у етнографској грађи из околине Пожаревца, Гласник Српског археолошког друштва 12: 219-226.

(Spasić, D. 1996

Primer arheološkog traga u etnografskoj građi iz okoline Požarevca, Glasnik Srpskog arheološkog društva 12: 219-226.)

\section{Спасић, Д. 1998}

Светиња манастира Нимника - од легенде до мита, Гласник Српског археолошког друштва 14: 315-325.

(Spasić, D. 1998
Svetinja manastira Nimnika - od legende do mita, Glasnik Srpskog arheološkog društva 14: 315325.)

Спасић-Ђурић, Д. 2015

Град Виминаиијум, Народни музеј Пожаревац, Пожаревац.

(Spasić-Đurić, D. 2015

Grad Viminacijum, Narodni muzej Požarevac, Požarevac.)

\section{Subotić, I. 2000}

Od Avangarde do Arkadije, Simboli $i$ enigme Milene Pavlović Barili, Clio, Beograd.

\section{Subotić, I. 2010}

The Two Lives of Milena Pavlović Barilli, in: Milena Pavlović Barilli Vero Verius, Vreme, Život, Delo (ed. Z. Stablović Bulajić), HESPERIAedu, Beograd: 280-299.

\section{Subotić, I. 2010b}

Three Fragments about Milena, in: Milena Pavlović Barilli Pro Futuro, Teme, Simboli, Značenja (ed. Z. Stablović Bulajić), HESPERIAedu, Beograd: 7-54.

\section{Taylor, K. 2008}

Taylor, Landscape and Memory: Cultural Landscapes, Intangible Values and Some Thoughts on Asia, in: 16th ICOMOS General Assembly and International Symposium, Finding the Spirit of Place - between the Tangible and the Intangible, 29 sept - 4 oct 2008, Quebec, Canada.

Tomić, V. (ed.) 2019

Milenin život, Danica Pavlović, Fondacija Milenin dom - Gareija Milene Pavlović Barili, Požarevac.

\section{UNESCO, 2019}

UNESCO World Heritage Centre, Operational Guidelines for the Implementation of the World Heritage Convention, UNESCO World Heritage Centre, Paris. 


\section{US-ICOMOS, 2004}

US-ICOMOS, Natchitoches Declaration on Heritage Landscapes, ICOMOS, Nathcitoches.

\section{Валтровић, М. 1884}

Откопавања у Костолцу, Старинар 1, 1-4 part:

3-142.

(Valtrović, M. 1884

Otkopavanja u Kostolcu, Starinar 1, 1-4 part: 3-142.)

\section{Валтровић, М. 1886а}

Римски натписи из Костоца, Старинар 3/1: 23 27.

(Valtrović, M. 1886a

Rimski natpisi iz Kostoca, Starinar 3/1: 23-27.)

\section{Валтровић, М. 1886b}

Остаци старе цркве у Костоцу, Старинар 3/2:

71.

(Valtrović, M. 1886b

Ostaci stare crkve u Kostocu, Starinar 3/2: 71.)

\section{Валтровић, М. 1886с}

Римско олово са жиговима, Старинар, 3/2: 7172.

(Valtrović, M. 1886c

Rimsko olovo sa žigovima, Starinar, 3/2: 71-72.)

\section{Валтровић, М. 1886d}

Старине из Костоца. Старинар 3/3(1886): 116. (Valtrović, M. 1886d

Starine iz Kostoca. Starinar 3/3(1886): 116.)

\section{Валтровић, М. 1890}

Римски натписи, Старинар VII/1: 52-56.

(Valtrović, M. 1890

Rimski natpisi, Starinar VII/1: 52-56.)

\section{Васић, М. 1903a}

Народни музеј Српској Краљевској Академији, Годишъак Српске краљевске академије XVI (1902/1903): 191-197.

(Vasić, M. 1903a
Narodni muzej Srpskoj Kraljevskoj Akademi-

ji, Godišnjak Srpske kraljevske akademije XVI (1902/1903): 191-197.)

\section{Васић, М. 1903b}

Извештај Српској Краљ. Академији Наука о ископавањима у Костоцу у год. 1902, Годишњак Српске краљевске академије XVI (1902/1903): 201-228.

(Vasić, M. 1903b

Izveštaj Srpskoj Kralj. Akademiji Nauka o iskopavanjima u Kostocu u god. 1902, Godišnjak Srpske kraljevske akademije XVI (1902/1903): 201-228.)

\section{Waldberg, P. 1970}

The Initiators of Surrealism, The New American Library by arrangement with UNESCO, New York.

\section{REZIME PIKTORALNA POETIKA MILENE PAVLOVIĆ BARILI I PREDEO VIMINACIJUMA}

\section{KLJUČNE REČI: MILENA PAVLOVIĆ BARILI, VIMINACIJUM, PREDEO, ANTIKA, NADREA- LIZAM, SLIKARSTVO, POETIKA.}

Asocijativni i inspirativni predeo kao kategorije kulturnih predela u oblasti zaštite kulturnog nasleđa omogućavaju da se za određen istorijski predeo vežu tragovi različitih vrsta umetnosti na čiji nastanak je predeo uticao, a koji nisu nužno hronološki uslovljeni. U ovom radu je prikazana interakcija predela i umetnosti/umetnika, na primeru arheološkog nalazišta Viminacijum nadomak Požarevca i svetski priznate slikarke Milene Pavlović Barili rođene u ovom gradu.

U pismima koja je slala majci Danici, Milena je uvek sa najvećom ljubavi pisala o rodnom kraju i sa toplom emocijom se sećala detinjstva provedenog u njemu, što se zaključuje i na osnovu zapisanih majčinih sećanja. Period Mileni- 
nog likovnog stvaralaštva između 1932. i 1936. i Protićevog zapažanja da je u detinjstvu mogla godine, Miodrag B. Protić nazvao je „linearnim“, videti ostatke antičke arhitekture i umetnosti na odnosno „parisko-rimskim“ periodom, dok ga Jelica Milojković naslovljava kao „linearno-antički“" period. Period je tematski najviše određen antičkim nasleđem, a tokom njega Milenina piktoralna poetika referira na antičku prošlost upotrebom motiva arhitektonskih elemenata, kao i skulptura ili ljudskih figura $u$ formi skulptura, te kompozicijskim rešenjima koja za potku imaju mitološke obrasce.

Obrazovanje koje je sticala u evropskim metropolama, posete velikim muzejima, kao i poznavanje savremenih umetničkih tokova metafizičkog realizma i nadrealizma, zasigurno su doprineli ovakvoj Mileninoj poetici. Ipak, tragom Mileninog pisma majci Danici iz 1943. godine području Požarevca bogatom arheološkim nalazištima, autorke ovog rada iznose mogućnost da je upravo Viminacijum mesto u čijem je materijalnom, ali i nematerijalnom nasleđu Milena našla motive i inspiraciju za dela nastala u periodu između 1932. i 1936. godine. Ovakav vid asocijativne veze u saglasnosti je sa konceptom nadrealizma koji je u ovom radu iskorišćen kao metod za povezivanje predela Viminacijuma i piktoralne poetike Milene Pavlović Barili. Shodno tome, određeni motivi Mileninih slika dobili su drugačiju interpretaciju koja na podsvesnom nivou sugeriše da ono što je umetnica videla u detinjstvu i mladosti kasnije u njenom slikarstvu izranja kao deo imaginarnog narativa. 